\title{
Performance Assessment of Public Health Center Madising Na Mario Parepare, South Sulawesi, Indonesia
}

\author{
Ajeng Dyah Pythaloka, Muh. Yusri Abadi \& Darmawansyah \\ Department of Administration and Health Policy, Faculty of Public Health, Hasanuddin \\ University, Makassar
}

\begin{abstract}
Implement health efforts both public health efforts are first rate and first rate individual health efforts are needed health center management be integrated and continuous in order to produce the performance of Public Health Center effective and efficient. This study aims to find out about the picture of the level of achievement of performance results pertaining to quality health center health center services, management of health centers and health care Public Health Center Madising Na Mario Pare-pare. This research method is quantitative descriptive method, whereby it purports to describe the level of achievement of the performance results of health centers. From the research achievement of quality performance owned health center services obtained an average value of 9,7 performance with good performance categories. Public Health Center management obtained an average performance score of 10 with a good performance categories. Health services obtained the value of the average performance of $70,9 \%$ with less performance categories. Therefore, efforts to improve the performance of health centers needed professional human resources and improvement of health facilities, especially the budget required.
\end{abstract}

\section{Article History}

Received 15 January 2019

Accepted 24 June 2019

\section{Keyword}

Achievement, performance, services, health center.

\section{Introduction}

The Public Health Centers is a Regional Public Service Agency (RPSA) which functions to provide health services to the public both in large cities and remote areas. In operational activities, public health centers are entities that do not prioritize profits so they must prioritize the principle of budget efficiency and optimal productivity (Mahardika and Supadmi, 2014). Health efforts are every activity to maintain and improve health, aiming to realize optimal health status for the public. Public health centers are basic health care facilities that carry out health care efforts, improve health (promotive), prevent disease (preventive), cure (curative), and restore health (rehabilitative), which are carried out in a comprehensive, integrated and sustainable manner. The concept of the unity of health efforts is a guideline and guideline for all health care facilities in Indonesia, including public health centers (Ministry of Health, 2014).

There are six main health service programs in the public health centers, namely treatment programs, health promotion, maternal and child health services, prevention and control of infectious and non-public diseases, and environmental health (Azwary, 2013). 
Implementing health efforts both first-level public health efforts and first-degree individual health efforts are needed by the health center management in an integrated and sustainable manner to produce effective and efficient public health centers performance (Republic Indonesia Ministry of Health, 2016). Realizing the vision, mission and goals of health centers needed a suitable management model and effective management model for health centers which consists of P1 (planning), P2 (mobilization and implementation), and P3 (monitoring, control and assessment) (Republic Indonesia Ministry of Health, 2012).

Performance assessment is a formal system for assessing and evaluating the performance of an individual or group task (Saputri, 2015). Evaluate the performance of health centers regularly conducted are crucial to ensure quality of service and supporting the implementation of the functions and organization of basic health measures which are the responsibility of the district / city. Based on this, the central government compiled guidelines for evaluating the performance of public health centers, which was an attempt to evaluate the evaluation of the work results or achievements of the health centers. The scope of the assessment of the performance of the public health centers includes evaluating the achievement of the results of the implementation of health services, management of the health center, and quality of service (Wijayani, et.al., 2017).

Madising Na Mario Health Center as the spearhead of basic health services in its work area makes every effort to realize healthy Indonesia by improving service and developing services and establishing harmonious cross-sector relations to improve the health status of the community in its Labukkang and Mallusetasi villages in accordance with its vision and the mission of the public health centers (Madising Na Mario Health Center, 2015). The data from the recapitulation of the calculation of the component coverage of the performance of the 2014 Madising Na Mario Health Center obtained an average score of 82\% (Madising Na Mario Health Center, 2014). To achieve the expected results, there are three components outlined in the health center performance appraisal, namely the quality service component of the health center, the health center management component and the health service component of the public health centers (Hestiwati, 2012). The performance evaluation of the public health centers is expected to provide an overview to each person in charge and executor at the public health centers about the level of achievement of the types of activities that are the responsibility and as an evaluation material / evaluation of his work performance

\section{Materials and Methods}

This type of research is quantitative descriptive. This research was conducted the Madising Na Mario Health Center in Parepare City, South Sulawesi, Indonesia. The population in the study was all the results of the performance of the public health centers with samples of all the results of the achievement of the public health centers performance related to the service quality of the public health centers, management of the public health centers and health services of the public health centers. The analysis used is an analysis of the performance of the public health centers in accordance with the public health centers management guidelines according to the Regulation of the Minister of Health of the Republic of Indonesia Number 44 year 2016. Data presentation will be developed in the form of tables and narratives. Tables are used for the presentation of the results of categorized data analysis and then accompanied by explanations in the form of narratives. 


\section{Results and Discussion}

Based on the achievement of the quality service performance of the Madising $\mathrm{Na}$ Mario Public Health Center in the Municipality of Parepare, the average performance value of the public health centers service quality was 9.7 in the good category. The number of indicators that have good performance with a score of 10 are 9 indicators including dropping out of Antenatal Care services delivery by health workers, handling high obstetric / risk complications, Acid Resistant Basil error rate, adherence to Antenatal Care standards, adherence to standards for examining pulmonary tuberculosis, the level of patient satisfaction with public health centers services, the availability of Public health centers service standards, and the health center quality team. The number of indicators that have sufficient performance achievements with a value of 7 is only one indicator, namely the malaria blood check error rate (Table 1).

Table 1: Results of Achieving Quality Services at Madising Na Mario Health Center in Parepare City

\begin{tabular}{lcc}
\hline \multicolumn{1}{c}{ Performance Program } & $\begin{array}{c}\text { Final } \\
\text { Score }\end{array}$ & $\begin{array}{c}\text { Performance } \\
\text { Category }\end{array}$ \\
\hline Antenatal Care drop out service & 10 & Good \\
Childbirth by health workers & 10 & Good \\
Handling high obstetric / risk & 10 & Good \\
Error rate exam for Acid Resistant Basil & 10 & Good \\
Error rate for malaria blood checks & 7 & Fair \\
Compliance with the standard & 10 & Good \\
Compliance checks Tuberculosis & 10 & Good \\
Satisfaction of health center services & 10 & Good \\
Availability of service operational & 10 & Good \\
Average health centers Performance & $\mathbf{9 . 7}$ & Good \\
\hline
\end{tabular}

Description: Performance of Puskesmas service quality: Good $=\geq 8.5$; Enough $=5.5$ - 8.4; Less $=<5.5$

The achievement of the management performance of the Madising Na Mario Public Health Center in the Municipality of Parepare shows that the average value of the health center management performance is 10 in the good category. All types of management have the same achievement value which is equal to 10 with good categories, including operational management of health centers, equipment and drug management, financial management, and staff management (Table 2).

Table 2: Results of Achieving Management Performance at Madising Na Mario Health Center in Parepare City

\begin{tabular}{lcc}
\hline \multicolumn{1}{c}{ Management Program } & $\begin{array}{c}\text { Final } \\
\text { Score }\end{array}$ & $\begin{array}{c}\text { Performance } \\
\text { Category }\end{array}$ \\
\hline Operational Management & 10 & Good \\
Tools and Medicine Management & 10 & Good \\
Financial management & 10 & Good \\
Labour Management & 10 & Good \\
Average health centers Management & 10 & Good \\
\hline
\end{tabular}

Description: Public health centers management performance: Good $=\geq 8.5$; Enough $=5.5$ 8.4; Less $=<5.5$ 
Based on the achievement of the health service performance of the Madising $\mathrm{Na}$ Mario Public Health Center in the Municipality of Parepare, it was shown that the average value of health center health service performance was $70.9 \%$ with less categories. Efforts to achieve performance in a good category, namely efforts to prevent and eradicate infectious diseases (96.3\%). Efforts to achieve poor performance were health promotion efforts $(62.7 \%)$, environmental health efforts (53.5\%), efforts to improve community nutrition $(79.7 \%)$, and health development efforts (38.1\%) (Table 3).

Table 3: Results of Achievement of Health Service Performance at Madising Na Mario Health Center, Pare-Pare City

\begin{tabular}{lcc}
\hline \multicolumn{1}{c}{ Health Efforts Program } & $\begin{array}{c}\text { Final } \\
\text { Score }\end{array}$ & $\begin{array}{c}\text { Performance } \\
\text { Category }\end{array}$ \\
\hline Health promotion efforts & 62 & Less \\
Environmental health efforts & 53 & Less \\
$\begin{array}{l}\text { Maternal and child health efforts including } \\
\text { family planning }\end{array}$ & 83 & Enough \\
Efforts to improve community nutrition & 80 & Less \\
Efforts to prevent and eradicate infectious & 96 & Good \\
diseases & 82 & Enough \\
Treatment efforts & 38 & Less \\
Health development efforts & 71 & Less \\
Average Public health centers Efforts & &
\end{tabular}

Description: Efforts of health center service coverage: Good $=\geq 91 \%$; Enough $=81-90 \%$; Less $=<80 \%$;

The achievement of the quality coverage of health services on average has had a level of achievement with a good category, but from 10 there is one sub-variable / indicator that is still in sufficient category with a value of 7 , namely an error rate of malaria blood checks. Malaria blood tests are categorized as sufficient because of a lack of budget, this examination is carried out in a large enough scope by the public health centers so that the implementation of the achievement of malaria blood checks is not optimal. Wildan, et.al (2016) stating that the structure is the infrastructure, equipment, tools, organization and management, finance, human resources and other funding sources. In other words, the structure is the input of health facilities. If the structure is good, the possibility of quality is also good. Whether or not the structure as input to health facilities can be measured by the reasonableness, quantity, cost, quality of the structural components.

The management of the public health center obtained by the public health centers is in a good category by optimizing the analysis of the problem, formulating the problem, the objectives of the activities, targets, targets and indicators of the success of the activities optimally. Mairizon and Kiswanto stated that it had not been done well that monthly miniworkshops and quarterly mini workshops were indicators of the weak implementation of the management functions of the public health centers in the implementation (Mairizon and Kiswanto, 2013). This causes unclear direction of the goals to be achieved and the division of tasks in achieving these conditions. The research conducted by Anton Ferri stated that the use of improper funds would result in errors in the preparation and distribution of services for carrying out activities, and would subsequently give a false picture in the financial statements (Ferri, 2009). As we know the number of operational funds is closely related to the number of products produced, thus an Public health centers institution engaged in health 
services, activity cost reports are used to determine the extent of the role of funds with the level of results of activities that have been carried out.

The results of the measurement of health service performance of public health centers which have a performance average value with less categories. The results of observations and research conducted by Steven Konli at the Gunawan Village Health Center show that health services to the community in the area have not been fully implemented (Konli, 2014). This is because the service personnel come in less on time, employee discipline is still lacking, the number of health workers is not in accordance with the number of patients who come, and the facilities and infrastructure are lacking so that these conditions make people less satisfied with the services provided. Pohan stated that health services that were not in line with patient expectations were expected to be input for health service organizations to try to fulfill them (Pohan, 2007). If the performance of health services obtained by patients at a health service facility is in line with their expectations, patients will always come to the health care facility. Patients will always seek health services at facilities whose health service performance can meet patient expectations.

\section{Conclusions}

The conclusion of this study is that the quality of public health centers services has a good performance, health center management has good performance, and health center health services have less performance. Suggestions to the health center and related parties so that it is necessary to prioritize indicators that have not yet been achieved properly in accordance with the target so that future coverage will be better so that it will ensure improved public health and better quality of public health centers services, and maintain Public health centers management whose targets have been well achieved.

\section{References}

Azwary, B. 2013. The Role of Medics in Improving Public Health Services in Kasai Village Health Center, Pulau Derawan District, Berau District. e-Journal of Government Science Vol. 1: 385-99

Ferri, A. 2009. Evaluation of Implementation of Integrated Public health centers Record and Reporting System in Karimun District. Yogyakarta: Gajah Mada University.

Hestiwati. 2012. Analysis of Performance Evaluation of Public health centers in Palu City, Central Sulawesi Province. Makassar, Hasanuddin University.

Konli, S. 2014. Public Health Services in Gunawan Village Health Center, Sesayap District, Tana Tidung Regency. e-Journal of Government Science, XI (2). 1925-1936

Madising Na Mario Health Center. 2014. Madising Na Mario Health Center Performance Report", Parepare City, Madising Na Mario Health Center.

Madising Na Mario Health Center. 2015. Profile of Madising Na Mario Health Center in ParePare City in 2015", Parepare City, Madising Na Mario Health Center.

Mahardika, K. and Supadmi, N.L. 2014. Comparative Analysis of South Denpasar and East Denpasar Public health centers Performance Using the Balaced Scorecard Method. EJournal of Accounting, Vol VIII (1): 1-13

Mairizon and Kiswanto. 2013. Implementation of Public Management Functions. Journal of Public Policy, Vol. 4. 119-218 
Ministry of Health. 2014. Republic of Indonesia Minister of Health Regulation Number 30 year 2014 concerning Standard Pharmaceutical Services at Public health centers. Jakarta, Ministry of Health.

Pohan, I.S. 2007. Quality Assurance of Health Services. Jakarta: Medical Book EGC

Republic Indonesia Ministry of Health. 2012. Ministry of Health Performance Accountability Report 2012. Jakarta, Ministry of Health of the Republic of Indonesia.

Republic Indonesia Ministry of Health. 2016. Minister of Health Regulation of the Republic of Indonesia Number 44 year 2016: Concerning Management Guidelines for Public health centers. Jakarta, Ministry of Health.

Saputri, I. 2015. Measurement of Internal and External Performance at Manukan Kulon Health Center Surabaya. Journal of Accounting Science and Research, Vol. II (2): 14-18

Wijayani, T.R.A., Utami, S., and Witcahyo, E. 2017. Relationship Between Organizational Culture Profiles (Using the Approach of the Competing Values Framework) with Community Health Organization Organizations in Jember Regency in 2012. Repository.

Wildan, M., Yuswadi, H., Wahono, P., and Puspitaningtyas, Z. 2016. Measuring Quality of Public Service Performance (National Health Insurance Program) with Patient Satisfaction Survey. Repository 